\title{
In Vitro Sitotoksisite Testleri
}

\author{
Orhan TOKUR*, Abdurrahman AKSOY
}

Ondokuz Mayıs Üniversitesi, Veteriner Fakültesi, Veterinerlik Farmakoloji ve Toksikolojisi Anabilim Dalı, Samsun, Türkiye.

Geliş Tarihi: 08.02.2017

Kabul Tarihi: 03.04.2017

\begin{abstract}
Özet: Kimyasal ve biyolojik maddeler ya da fiziksel etkenler, hücreleri değişik derecelerde etkileyerek sitotoksisiteye yol açabilirler. Bir maddenin biyolojik davranışının anlaşılabilmesi için hücreler üzerindeki toksik ya da non-toksik etkisinin belirlenmesi gereklidir. İ vitro sitotoksisite testleri, ilaç niteliği taşıyan veya toksik profili araştırılan maddelerin değerlendirilmesi amacıyla hücre kültüründe gerçekleştirilen ölçüm metodlarıdır. Bu testlerle çok sayıda maddenin kısa sürede analiz edilmesi mümkün olmakta ve yapılacak hayvan denemeleri için temel veriler elde edilebilmektedir. Farklı mekanizmalara ve hassasiyetlere sahip çok sayıda sitotoksisite testi bulunmakla birlikte bu derlemede, araştırmacılar tarafından sıkça tercih edilen tetrazolyum testleri (MTT, MTS, XTT, WST), LDH testi, alamalar mavisi testi ve biyolüminesans testleri ele alınmıştır.
\end{abstract}

Anahtar Kelimeler: In vitro, Sitotoksisite, Hücre canlıık testleri.

\section{In Vitro Cytotoxicity Assays}

\begin{abstract}
Chemical, biological and physical factors may cause cytotoxicity by affecting cells at different degrees. To understand the biological characteristic of a compound, it is essential to determine its toxic or non-toxic effects. In vitro cytotoxicity assays (cell viability assays) are cell culture based measuring methods that usually used for either evaluating possible drug candidates or investigating cytotoxic profiles of some compounds. It is possible to assess many compounds in a short period of time and obtain fundamental information necessary for further animal experiments through this methods. There are many cell viability assay methods exist based on colorimetric, enzymatic, luminometric principals etc that have different mechanisms and varied sensitivity. The popular assays, such as MTT, MTS, XTT, WST, LDH enzyme assay, alamar blue assay, ATP bioluminescent assay have summarized in this rewiev.
\end{abstract}

Keywords: In vitro, Cytotoxicity, Cell viability assays.

\section{GiRiş}

Hücre kültürü, çok hücreli organizmalara ait hücrelerin, laboratuvar ortamında özel olarak tasarlanmış kaplarda, ISI, nem, besin gibi ortam şartlarının kontrol edilerek kontaminasyondan ari bir şekilde yaşatılmasıdır. İnsan da dâhil olmak üzere herhangi bir canlıdan alınan hücrelerin suni ortamda yaşatılabilmesi, herhangi bir doku ya da organdan alınan hücrelerin kullanılabilmesi ve birçok etik kaygıyı gidermesi, hücre kültürü çalışmalarının tercih sebepleri arasında yer almaktadır (Zucco ve ark., 1998). Hücre kültürünün sıkça tercih edildiği alanlar kanser, aşı çalışmaları, ilaç geliştirilmesi ve in vitro sitotoksisite çalışmalarıdır (Gilbert ve Boutros, 2016). Sitotoksik terimi, hücre ölümüne neden olan anlamına gelmektedir. Sitotoksisite araştırmaları, bir maddenin sitotoksik potansiyelinin olup olmadığının belirlenmesi amacıyla yapılır. Hücre temelli sitotoksisite çalışmaları, gerek uygulama kolaylığı, gerekse in vivo çalışmalardan elde edilen verilerle uyum göstermesi nedeniyle, hayvan deneylerine alternatif olarak doğmuş ve toksikoloji laboratuvarlarında sıkça tercih edilir hale gelmiştir (Riss ve Moravec, 2004). Sitotoksisite, incelenen maddenin dozuna ve maruziyet süresine bağılı olarak hücrelere değişik derecelerde zarar veren bir olaydır. Hücreler, sitotoksik maddeye maruz kalırsa apoptoz, otofaji ve nekroz gibi olaylar sonucu ölebilir ya da sitostazis nedeniyle proliferasyon özelliklerini kaybedebilirler (Galluzzi ve ark, 2009). Hücre bazlı sitotoksisite çalışmaları ile test edilen maddenin sitostatik ve sitotoksik etkileri hakkında temel bilgi edinilir (Riss ve ark., 2006). Deneysel olarak kimyasal, biyolojik ya da fiziksel etkenlere maruz bırakılan hücrelerin, maruziyet sonrasındaki canlııklarının belirlenmesi, bu çalışmaların önemli bir basamağıdır (Niles ve ark., 2007). Hücre canlılı̆ının belirlenmesi için uygulanan çok sayıda test vardır. Yapılan sitotoksisite çalışmasının tipi ne olursa olsun, önemli olan çalışma sonundaki canlı/ölü hücre miktarının belirlenmesidir (Riss ve ark., 2006). Sitotoksisite belirleme metodları genel olarak kolorimetrik, lüminesans ve enzimatik yöntemlerdir (Crouch ve ark., 1993; Fan ve Wood, 2007; Longo-Sorbello ve ark., 2006).

Kolorimetrik metodlarda, 3-(4,5-dimetiltiyazol2-yl)-2,5-difeniltetrazolyum-bromür (MTT), 3-(4,5dimetiltiyazol-2-yl)-5-(3-karboksimetoksifenil)-2-(4sülfofenil)-2H-tetrazolyum (MTS), 2,3-bis-(2metoksi-4-nitro-5-sülfofenil)-2H-tetrazolyum-5karboksianilid (XTT), 2-(4-iodofenil)-3-(4-nitrofenil)5-(2,4-disülfofenil)-2H-tetrazolyum (WST) gibi tetrazolyum tuzları kullanılarak renk değişikliği ya da kristal viyolet, nötral kırmızısı gibi boya maddeleri 
kullanılarak hücrelerin spesifik boyanması esasına dayalı ölçüm yapılır (Borenfreund ve Puerner, 1985; Feoktistovave ark., 2016; O'Connor ve ark., 1998; Riss ve ark., 2006). Luminometrik metodlar, floresans ve biyolüminesans olarak ikiye ayrılmaktadır. Floresans metodlarda, floresans özellikteki maddeler kullanılırken, biyolüminesans metodlarda lusiferaz denilen özel enzimler ve bunların substratlarının kullanımı ile canlı/ölü hücre tespiti yapılması söz konusudur. Daha gelişmiş biyolüminesans metodlarda (gerçek zamanlı biyolüminesans), hücrelerin sitotoksik madde ile maruziyeti, sadece testin yapıldığı anda değil, maruziyet süresince incelenebilir hale gelmiştir (Duellman ve ark., 2015). Hücre hasarını ya da ölümünü takiben vasata sızan enzimler de ölü hücre sayısının belirteci olarak ele alınmıştır. Bu enzimler içerisinde stabilitesi ile öne çıkan laktat dehidrojenaz (LDH), hücre ölümü belirteci olarak canlılık testleri arasındaki yerini almıştır (Korzeniewski ve Callewaert, 1983).

Hücre sayısı tespitinde kullanılan metotlar içerisinde, mikroskopi (tripan mavisi ile boyamathoma lamı) ya da elektronik sayıcı ile otomatik sayım gibi, özellikle rutin hücre kültürü işlemlerinde kullanılan metodlar da bulunmaktadır. Ancak bu metodlar çok zaman alması nedeniyle, çok sayıda numune kullanılan (mikropleyt formatı) çalışmalar için uygun değildir (Connolly ve ark., 1986). Çok sayıda maddeyi kısa sürede pratik olarak değerlendirebilmek, mikropleytler ve bunlara uyarlanan testlerin geliştirilmesiyle mümkün olmuştur ve "ekle-karıştır-ölç" prensibiyle hem zamandan kazanılmış hem de uygulama kolaylığı sağlanmıştır (Riss ve Moravec, 2006; Weyermann ve ark., 2005).

Tetrazolyum Tuzları ile Yapılan Testler: Tetrazolyum tuzları, heterosiklik organik yapıda bileşiklerdir. Keşfedildiği yıllardan günümüze kadar 1000'i aşkın üyesi sentezlenmiş ve tanımlanmıştır (Altman, 1976). Tetrazolyum tuzlarının elektron alarak indirgenmeleri, formazan denilen yapıya dönüşmelerini sağlayarak, renk değişikliğini beraberinde getirir. Tetrazolyum halkası ancak aktif mitokondri tarafından kırılabilir ve böylece renk reaksiyonunu yalnızca canlı hücreler meydana getirebilirler (Mossman, 1983). Ölü hücreler ise tetrazolyum bileşiklerini indirgeme yeteneklerini kaybeder ve herhangi bir renk değişimine neden olmazlar (Riss ve Moravec, 2006). Bu değişimin, in vitro ortamda yalnızca canlı hücreler tarafından yapılabilmesi, tetrazolyum bileşiklerini biyolojik anlamda oldukça önemli kılmıştır (Altman, 1976). Mossman (1983) tarafından geliştirilen MTT testinden sonra, XTT, MTS, WST-1, WST-8 gibi farklı özelliklere sahip tetrazolyum bileşikleri geliştirilerek kolorimetrik metodlara eklenmişlerdir (Barltrop ve ark., 1991; Ishiyama ve ark., 1995; Mossman, 1983; Paull ve ark., 1988; Scudiero ve ark., 1988; Tominaga ve ark., 1999). Sıkça kullanılan bazı tetrazolyum bileşiklerinin kimyasal yapıları Şekil 1 'de gösterilmiştir.

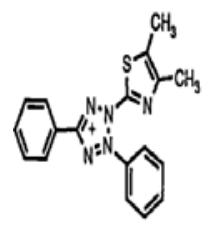

mT

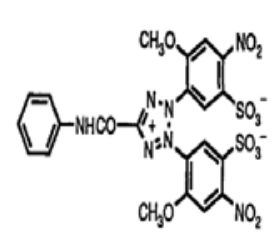

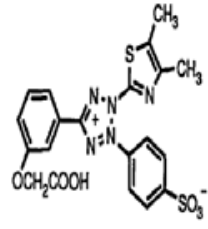

Şekil 1. MTT, XTT ve MTS bileşiklerinin kimyasal yapıları (Barltrop ve ark., 1991'den).

Araştırmalarda, çok sayıda tetrazolyumformazan maddesi kullanılmış olmakla beraber bunlardan sadece birkaç tanesi kabul görmüş ve biyolojik sistemlere uyarlılığı sağlanmıştır (Altman, 1976; Barltrop ve ark., 1991). Bu bileşikler, hücre içine girebilme ve vasatta çözünme özelliklerine göre ikiye ayrılırlar. Illk grupta bulunan MTT, pozitif yüklü bir bileşik olup, ökaryot hücrelerin membranını kolaylıkla geçerek hücre içinde indirgenebilir ancak indirgenme sonucu oluşan formazan, suda çözünmez niteliktedir ve dolayısıyla vasatta kristal şeklinde çökelmektedir. İkinci grupta bulunan MTS, XTT ve WST bileşikleri ise negatif yüklü olup hücre membranını geçemezler. Bu yüzden ilgili bileşiklerle birlikte ara elektron alıcı moleküllerin (fenazin metil sülfat, fenazin etil sülfat) kullanılması zorunluluğu doğar. Elektron alıcı molekül, hücre içerisine girerek sitoplazmadan ya da plazma membranından elektron alır ve vasata geri dönerek tetrazolyum bileşiğini indirger. İkinci gruptaki bileşiklerin indirgenmesi sonucu oluşan formazan ise suda ve dolayısıyla vasatta çözünebilir niteliktedir (Riss ve ark., 2016). Tetrazolyum bileşikleri ile yapılan canlılık testleri, üç aşamada gerçekleştirilmektedir. İlk aşamada hücreler belirli bir süre toksik maddeye maruz bırakılırlar. İkinci aşamada toksik madde uzaklaştırılıp tetrazolyum bileşiği vasata eklenir ve ortalama 1-4 saat boyunca inkübe edilir. Bu esnada canlı hücreler ilgili bileşikleri indirgeyip formazana dönüştürürek renk değişimini gerçekleştirir. Son aşamada ise renk değişimi spektrofotometrik yöntemle ölçülerek canlı/ölü hücre sayısı belirlenir (Mossman, 1983; Riss ve Moravec, 2004). MTT test belirteci eklendikten oluşan renk değişimi Şekil 2'de gösterilmiştir.

Ölçüm sonucu oluşan sinyal miktarı, tetrazolyum tuzu konsantrasyonu, hücre tipi, canlı hücre sayısı ve metabolik kapasitesi, vasat içeriği, vasat $\mathrm{pH}^{\prime}$ ı, pleyt-flask ya da kuyucuk yapısı gibi 
parametrelerle doğrudan ilişkilidir (Denizot ve Lang, 1986; Riss ve ark., 2016). MTT bileşiği sarı renklidir, oluşan formazan ise mor renkli olup suda çözünmez niteliktedir ve absorbansın ölçülebilmesi için uygun bir çözücüde çözdürülmelidir. Denizot ve Lang (1986) tarafından, MTT testinde oluşan formazanı çözdürmek için dimetil sülfoksit (DMSO) kullanımının uygun olduğu ortaya konulmuştur. Çözücü olarak genellikle tercih edilen DMSO'nun hücreler üzerine olan toksik etkisi bilinmektedir ve bu da test güvenilirliğini azaltmaktadır (Paull ve ark., 1988). Ayrıca çözdürmek için yapılan pipetleme esnasında formazan kristallerinin zarar görmesi de test hassasiyetini düşüren diğer bir etkendir (Martin ve Clynes, 1993). XTT, MTS ve WST testlerinde, ek bir çözdürme işlemine gerek duyulmamasının yanında, deney süresince çeşitli zamanlarda absorbansın kaydedilmesi mümkün olmaktadır. Bu sayede canlılığın değerlendirilmesi hakkında daha detaylı ve hücre sayısı hakkında MTT testine nazaran daha hassas bilgi sunarlar. Bu gruptaki tetrazolyum tuzları, kimyasal özellikleri dolayısıyla kendileriyle beraber elektron bağlayıcı ajanların (electron coupling agent, PES) kullanımın gerektirmektedirler (Barltrop ve ark., 1991; Riss ve Moravec, 2006).

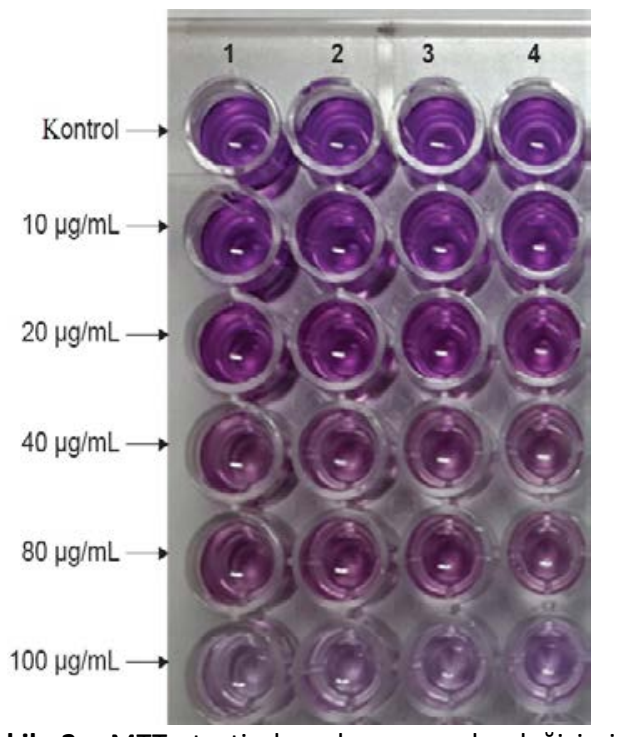

Şekil 2. MTT testinde oluşan renk değişimi (Aravinthan ve ark., 2015).

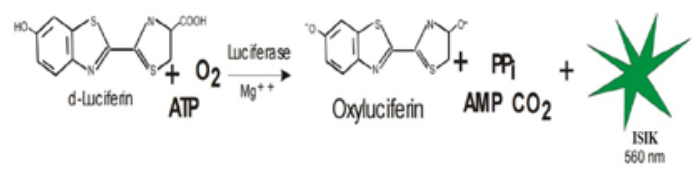

Şekil 3. ATP biyolüminesans reaksiyonu (Held P, 2004'ten uyarlanmıştır).
LDH Enzim Salıverilmesi Testi: Hücre canlılığının değerlendirilmesinde kullanılan diğer bir metot ise hasarlı/ölü hücrelerden vasata salınan laktat dehidrojenaz (LDH) aktivitesinin belirlenmesidir (Decker ve Lohmann-Matthes, 1988; Korzeniewski ve Callewaert, 1983). Laktat dehidrojenaz, tüm hücrelerde bulunan sitoplazmik bir enzimdir. Hücreler, toksik etkilere maruz kaldığında plazma membran bütünlükleri bozulur ve $\mathrm{LDH}$ enzimi hücrelerden sızarak vasata geçer. Böylece maruziyet sonrası LDH enzim aktivitesi ölçülerek hücre hasarı değerlendirilebilir (Lappalainen ve ark., 1994; Riss ve Moravec, 2006).

LDH aktivitesinin belirlenmesi için uygulanabilecek iki farklı metot bulunmaktadır. İlk metotta kullanılan test belirteci, hücrelere toksik olması dolayısıyla LDH salınımına neden olup test değerlerini bozabilmektedir. Bu nedenle hücrelerin toksik madde ile maruziyeti sonrası, kuyucuklardan alınan bir miktar vasat başka bir mikropleyte aktarılır ve test belirteci eklenerek birkaç saat inkübe edilir (Riss ve Moravec, 2006). İnkübasyon sırasında vasatta bulunan LDH, pirüvatın laktata dönüşümünü katalize eder. Bu enzimatik aktivite esnasında, $\mathrm{NADH}$ oksidasyona uğrayarak $\mathrm{NAD}^{+\prime}$ a dönüşür. İncelenen vasattaki NADH miktarı, $340 \mathrm{~nm}$ absorbansta, mikropleyt okuyucu ile belirlenerek test tamamlanır (Decker ve Lohmann-Matthes, 1988; Lappainen ve ark., 1994; Riss ve Moravec, 2002). İkinci yöntemde resazurin boyası ve diaforaz enzimi kullanılmaktadır. Test belirteci, direkt hücreler üzerine eklenir. On dakikalık inkübasyon süresi yeterlidir. Bu metot, diaforaz enziminin katalize ettiği bir reaksiyonla, vasatta bulunan NADH'ın, resazurin boyasını floresans bir madde olan resorufin'e indirgemesi ve sonrasında floresans sinyalinin florometre ile ölçümü prensibine dayanmaktadır. (Riss ve Moravec, 2006). LDH testi ile ölçülen enzimatik aktivitenin zamana bağlı olarak doğal yıkımlanmaya uğrayabilmesi, $\mathrm{pH}$ ve vasat kompozisyonundan etkilenebilmesi, hassasiyetini düşüren dezavantajlarından bazılarıdır (Galluzzi ve ark., 2009). Hücreler hasar aldıktan ya da öldükten sonra vasata geçen $\mathrm{LDH}^{\prime}$ ıın yarı ömrü ortalama 910 saat kadardır. Toksik madde ile uzun süreli maruziyet gerektiren çalışmalarda, LDH'nın yarı ömrü ve çoğalan hücrelerin LDH oranını değiştirmesi gibi faktörler, hassasiyeti düşürmektedir. Örneğin; 48 saatlik maruziyet periyodu belirlenen bir çalışmada, 48 saatlik sürenin başında ölen hücrelerden vasata salınan LDH aktivitesi en geç 12 saat içerisinde sonlanacak ve deney sonunda tespit edilemez hale gelecektir. Sayılan bu nedenlerden ötürü LDH testi uzun süreli maruziyet çalışmalarına uygun değildir (Riss ve ark., 2006). Farklı hücre hatlarından köken alan ve vasata salınan $L D H^{\prime}$ nın stabilitesi farklılık göstermektedir. Özellikle 
fibroblastların endojen LDH seviyeleri düşük olduğu için bu hücre hattıyla LDH testinin kullanımı uygun değildir (Zucco ve ark., 1998).

\section{Lüminesans Metodlar:}

a) Alamar Mavisi Floresans Testi ve Diğer Floresans Metodlar: Alamar mavisi testi, Erb ve Ehlers (1950) tarafından, biyolojik sıvılarda ve sütte bakteriyel kontaminasyonun belirlenmesi amacıyla ilk kez 1950'lerde kullanılmış, daha sonra Ahmed ve ark. (1994), bu testi radyoaktif $\left[{ }^{3} \mathrm{H}\right]$ timidin birleşme testine alternatif olarak hücre kültürüne uyarlamıştır. Bu metot, alamar mavisi (resazurin) adlı bileşiğin, canlı hücreler tarafından resorufin bileşiğine dönüştürülmesi esasına dayanmaktadır. Resazurin, oksidatif formda bulunan koyu mavi renkte bir redoks boyasıdır, hücre zarından serbestçe geçerek hücrelere girer ve burada indirgenerek floresans özellikteki pembe renkli resorufin bileşiğine dönüşür. Ölü hücreler, metabolik aktivitelerini kaybettikleri için resazurini indirgeyemez ve floresans sinyali oluşturamazlar. Oluşan sinyal, florometre kullanılarak tespit edilir ve canlı hücre sayısı arttıkça sinyal şiddetlenir (Ahmed ve ark., 1994; O'brien ver ark., 2000; Riss ve Moravec, 2006; Silva ve ark., 2016).

Resazurin, PBS içerisinde çözünebilmektedir. Hücrelerin toksik madde ile maruziyeti sonrası, resazurin taşıyan test belirteci, direkt olarak vasata eklenerek uygun bir inkübasyon periyodu sonrasında ölçüm yapılarak test tamamlanır. Metabolik aktivitesi düşük hücre hatları ile yapılan çalışmalarda, yeterli sinyal oluşumunun sağlanması için inkübasyon süresinin artırılması oldukça önemlidir (Riss ve Moravec, 2006; Silva ve ark., 2016). Alamar mavisi testinde, lizis, ekstraksiyon ve yıkama gibi zaman ve emek gerektiren prosedürler bulunmamaktadır. pH değişikliklerine karşı dayanıklılığı gösterilen alamar mavisi testi, fötal dana serumu ve fenol kırmızısı içeren vasatlarda kullanıldığında, bu maddelerin ölçüm esnasında herhangi bir sinyal gürültüsüne yol açmadığı gösterilmiştir (Ahmed ve ark., 1994; Silva ve ark., 2016).

Alamar mavisi testinde, renk değişikliği oluştuktan sonra, hücreler vasattan çıkarılsa ya da sonradan ölse dahi renk değişikliği sabit kalır ve bu da kullanımını sınırlayan nedenlerden biridir. Hücrelerin üreme ve gelişmeleri sırasında ortama verdikleri metabolitler ve vasat kompozisyonundan oldukça etkilenen alamar mavisi, hücreler öldükten sonra metabolitleri halen vasatta bulunduğu için tekrar eski okside formuna dönemez ve bu da testin belirleyiciliğini negatif etkiler (Ahmed ve ark., 1994; Squatrito ve ark., 1995). Alamar mavisi dışında, hücre canlılı̆ını belirlemede kullanılan proteaz ve esteraz enzim aktivitesine dayalı iki farklı floresans metodu bulunmaktadır. Bu metodlar, canlı ve ölü hücrelerin, proteaz ve esteraz aktivitesi yönünden ayrılması prensibine dayanmaktadır (Niles ve ark., 2007, Sali ve ark., 2016). Proteaz aktivitesine dayalı metotta, hücre zarını geçebilen florojenik proteaz substratı (glisilfenilalanil-aminoflorokumarin; GF $\mathrm{AFC}$ ), canlı hücreler içerisine girer, sitoplazmik aminopeptidazlar tarafından glisin ve fenil amino asitlerinin uzaklaştırılmasıyla floresans sinyali yayan aminoflorokumarine (AFC) dönüştürülür ve böylece canlı hücre sayısı hakkında bilgi verir. Ayrıca GF-AFC substratına benzer şekilde, yine proteaz substratı bir peptid olan ancak hücre içine girme yeteneği olmayan rodamin (aminolusiferin), hücre ölümünü takiben vasata geçen proteazlar tarafından florojenik formuna dönüştürülür ve böylece ölü hücre sayısı hakkında bilgi verir. Metot, iki farklı substrattan birinin uygulanması şeklinde yapılabilse de bu iki belirtecin kombine halde uygulanması, proteaz testinin hassasiyetini önemli ölçüde artırmaktadır (Niles ve ark., 2007). Esteraz aktivitesinin ölçümüne dayalı metotta ise ester formunda substrat halinde bulunan kalsein-asetoksi-metilester (CAM) isimli madde, sadece canlı hücrelerin ester bağlarını kırabileceği prensibine dayanarak hücre canlılığını belirlemektedir. Canlı hücreler tarafından ester bağının yıkımlanmasıyla oluşan serbest kalsein, hücre içerisinde kalarak floresans gösterir ve oluşan sinyalin ölçümü florometre ile yapılır (Sali ve ark., 2016).

b) ATP Biyolüminesans Testi: Adenozin trifosfat (ATP) molekülü, biyolojik sistemlerde enerji kaynağı olarak görev yapar ve metabolik olarak aktif tüm hücrelerde bulunur (Crouch ve ark., 1993). Hücre ölümünü takiben, hücrenin ATP sentez yeteneği kaybolur ve endojen ATPazlar mevcut ATP'yi hızlı bir şekilde yıkımlarlar. Bu nedenle intrasellüler ATP içeriği, hücre canlılığının temel göstergesi olarak nitelenmiş ve canlılık belirleme metodları arasındaki yerini almıştır. ATP biyolüminesans testi, multipleytlerde yapılan canlılık testleri arasında en hızlı, en hassas ve en kolay metot olarak tanımlanmaktadır (Lomakina ve ark., 2015; Riss ve ark., 2006).

ATP konstrasyonunun ölçülebileceği, enzimselspektrofotometrik, radyografik, biyolüminesans gibi farklı metodlar mevcuttur. Biyolüminesans metodu, bunların içerisinde en hassas metot olması dolayısıyla ön plana çıkmıştır (Lomakina ve ark., 2015). Lüminesans özellik gösteren çok sayıda biyolojik madde bulunmakla beraber bu zamana kadar bunlardan sadece üç tanesi, Firefly (ateşböceği-Photuris Pennsylvanica), Renilla ve Aequorin isimli canlılardan elde edilen substratlar, biyolüminesans testlerine uyum sağlayabilmiş ve kullanıma girmiştir. ATP biyolüminesans testi, 
normalde ateş böceklerinde meydana gelen biyolüminesans reaksiyonunun takliti prensibine dayanır. Lusiferaz ve bu enzimin substratı olan lusiferin, test belirteci olarak kullanılarak, hücrelerde bulunan ATP aracılığıyla lüminesans oluşumu sağlanır (Fan ve Wood, 2007; Riss ve Moravec, 2006). Lusiferaz enzimi, 61 kDa ağırlığında monomerik bir enzimdir. Bu enzim, öncelikle lusiferin ile ATP'yi birbirine bağlayarak lusiferil-AMP ara ürününü meydana getirir. $\mathrm{Bu}$ ürün ise magnezyum iyonları varlığında, oksijen ile reaksiyona girerek oksitlenir ve eksite enerji düzeyindeki bir bileşik olan oksilusiferine dönüşür. Oksilusiferin, kararlı enerji düzeyine dönerken fazla enerjisini foton olarak yayar ve sarı-yeşil renkte ışı oluşturarak $560 \mathrm{~nm}$ dalga boyunda maksimum absorbans verir (Fan ve Wood, 2007; Lomakina ve ark., 2015).

ATP biyolüminesans testinde kullanılan test belirteci içerisinde, canlı hücreleri lize edip ATP içeriğini açığa çıkarmak için deterjan, asit vb maddeler, çıkarılan ATP'nin yıkımlanmasını önlemek için ATPaz inhibitörleri, lusiferaz, lusiferin, buffer ve stabil bir lüminesans sinyali oluşturmak için gerekli şartları sağlayan diğer maddeler bulunmaktadır. Lusiferaz enzimi, hücre içine penetre olamadığı için canlı hücrelerde bulunan ATP miktarını ölçememekte ve bu nedenle hücrelerin lize edilmesi gerekmektedir. Hücreleri lize etmek için deterjan maddeler ve karışımları, güçlü asitler (perklorik asit, triklorasetik asit), organik solventler (butanol, kloroform, dimetil sülfoksit) gibi farklı maddeler kullanılmaktadır (Lomakina ve ark., 2015). Sali ve ark. (2016), perklorik asit ile yapılan lizis işlemini altın standart olarak tanımlamıştır. Test, toksik madde ile maruziyeti takiben hücrelerin lize edilmesi, açığa çıkan ATP'nin, lusiferin-lusiferaz ile reaksiyona girmesi ve oluşan lüminesans sinyalinin luminometre ile ölçülmesi sırasıyla gerçekleştirilmektedir (Crouch ve ark., 1993; Lomakina ve ark., 2015; Riss ve ark., 2006). Lüminesans sinyali, alternatif olarak bazı florometre modelleri ile de ölçülebilir ancak bunlar luminometre kadar hassas değildir (Riss ve ark., 2006). ATP testinin uygulama kolaylığı, hızlı sonuç vermesi ve canlılık testleri arasındaki en hassas test olması, öne çıkan özellikleri arasındadır (Petty ve ark., 1995; Riss ve Moravec, 2006; Weyermann ve ark., 2005). ATP testi, yüksek düzeydeki hassasiyeti nedeniyle, çok daha fazla sayıda maddenin eş zamanlı olarak incelenmesine imkan veren 1536'lık mikropleyt formatına uygundur (Riss ve ark., 2016). Test için gerekli luminometre cihazı, her laboratuvarda bulunmamakta ve bu testin maliyeti, en önemli dezavantajı olarak ortaya çıkmaktadır (Riss ve Moravec, 2006). c) Gerçek Zamanlı (Real Time) Biyolüminesans Testi: Canlılık testlerinin büyük çoğunluğu, hücreleri yok eden veya daha ileri incelemelere izin vermeyen son test (end-point) formatındadır ve bu da toksik maddenin kinetiğini ve gerçek zamanlı analizini imkânsız hale getirmektedir. Toksisite, zaman ve doza bağlı olduğu için, farklı doz aralıklarının etkileri ancak farklı zamanlarda incelenerek anlaşılabilir. ATP biyolüminesans testine benzer şekilde bu testte de lusiferaz enzimi kullanılmaktadır. Ancak bu testte kullanılan lusiferaz enzimi, farklı bir canlıdan elde edilir. Lusiferaz prosubstratı olarak ise koelenterazin denilen bir madde kullanılmaktadır (Duellman ve ark., 2015).

Renilla lusiferazı, Sea Pansy (Renilla reniformis) isimli bir çeşit deniz canlısından elde edilen 36 kDa ağırlığındaki monomerik bir enzimdir. Koelenterazin, hücre içine serbestçe girebilme özelliğine sahiptir ve üzerinde bazı kimyasal modifikasyonlar yapılarak, lusiferaz ile etkileşemez hale getirilmiştir. Toksik maruziyet sonrası hücreler üzerine eklenen koelenterazin, canlı hücreler tarafından üzerindeki modifikasyonlar uzaklaştırılmak suretiyle esas formuna döndürülür ve lusiferaz ile etkileşerek okside olup koelenteramide dönüşür. Koelenteramid bileşiği eksite enerji düzeyindedir ve kararlı hale geçerken $480 \mathrm{~nm}$ dalga boyunda maksimum absorbans veren mavi renkte ışınım yapar. Ölü hücreler, metabolik aktiviteleri bulunmadığı koelenterazini asıl formuna dönüştüremez ve herhangi bir sinyal oluşumuna yol açamazlar. Oluşan sinyal, canlı hücre sayısı ile doğru orantılıdır. Bu metotta kullanılan Renilla lusiferazı ile ATP biyolüminesans metodunda kullanılan Firefly lusiferazı arasındaki en önemli fark, Renilla lusiferazının ATP'ye intiyaç duymamasıdır. Böylece hücreleri lize etmeye gerek duyulmamakta, gerçek zamanlı inceleme mümkün olmaktadır. Ayrıca bu metodun son test formatında olmayışı, diğer testlerle kombine edilerek daha detaylı sonuç alınabilmesini sağlamaktadır (Duellman ve ark., 2015; Fan ve Wood, 2007; Riss ve ark., 2006; Verhaegen ve ark., 1998). Gerçek zamanlı biyolüminesans testinin dezavantajlarından biri, vasata eklenen prosubstratın, canlı hücrelerce metabolize edilerek bir süre sonra tüketilmesi iken diğeri, testin yüksek maliyetidir (Riss ve ark., 2016).

\section{Sonuç}

Sitotoksisite testleri, ilaç olması muhtemel ya da toksik etkisi bilinmeyen bir maddenin davranışı hakkında temel bilgiler verir ve daha sonra yapılacak hayvan denemeleri veya klinik denemelere kaynak oluşturur. Bu nedenle, ilgili çalışmalardan elde edilecek verilerin doğruluğu ve güvenilirliği önemlidir. Geçmiş yıllarda, sitotoksisite sonrası hücrelerin 
canlılığını değerlendirmek için çok sayıda metot geliştirilmiş ve her metodun kendine göre avantaj ve dezavantajları tanımlanmıştır. Ancak araştırmacılar tarafından halen eski ve çok sayıda dezavantaja sahip metodların (MTT testi gibi), gerek uygulama kolaylığı gerekse maliyetleri dolayısıyla tercih edildiği görülmektedir. Bu sahadaki son gelişmelerden biri olan gerçek zamanlı biyolüminesans görüntüleme, hassasiyetini ve kalitesini ispatlamış bir metot olsa da, gerektirdiği ekipman ve sarf malzemelerin maliyeti dolayısıyla henüz yaygınlaşmamıştır. Birçok araştırmacı, uygun metot seçiminden bahsederken maliyeti de göz önünde bulundurulması gerekli koşullardan biri saymıştır ancak, testlerden elde edilen verilerin önemi göz önüne alındığında, maliyetin ön planda olmaması gerektiği kanısına varılmaktadır. Bir kısım araştırmacılar ise, hassasiyet kaygısını gidermek için çeşitli metodların kombinasyonunu tercih etmiş ve bu durumun güvenilir sonuçlar sunması açısından uygun olduğu düşünülmüştür. Yapılan testlerden elde edilen verilerin kalitesi yalnızca metoda bağlı değil, araştırmacının bilgi ve tecrübesi, kullanılan hücre tipi, ortam sıcaklığı, test belirteci içeriği ve vasat kompozisyonu gibi çok sayıda değişkene bağlıdır. Test sonuçlarındaki başarı, tüm bu değişkenlerin bir arada göz önünde bulundurulmasını gerektirmektedir. Gelecekte, hücresel mekanizmaların ve hücresel yapıların daha detaylı aydınlatılması ile farklı canlılık belirteçlerinin keşfedileceği ve çok daha hassas derecede tespit yapılabileceği düşünülmektedir.

\section{Kaynaklar}

Ahmed SA, Gogal RM Jr, Walsh JE, 1994: A new rapid and simple non-radioactive assay to monitor and determine the proliferation of lymphocytes: an alternative to $\left[{ }^{3} \mathrm{H}\right]$ thymidine incorporation assay. $J$ Immunol Methods, 170, 211-224.

Altman FP, 1976: Tetrazolium salts and formazans. Prog Histochem Cytochem, 9(3), 3-6.

Aravinthan A, Govarthanan M, Selvam K, Praburaman L, Selvankumar T, Balamurugan R, Kamala-Kannan S, $\mathrm{Kim} \mathrm{JH}$, 2015: Sunroot mediated synthesis and characterization of silver nanoparticles and evaluation of its antibacterial and rat splenocyte cytotoxic effects. Int J Nanomedicine,1977-1983.

Barltrop JA, Owen TC, Cory AH, Cory JG, 1991: 5-(3carboxymethoxyphenyl)-2-(4,5-dimethylthiazolyl)-3(4-sulfophenyl)tetrazolium, inner salt (MTS) and related analogs of 3-(4,5-dimethylthiazolyl)-2,5diphenyltetrazolium bromide (MTT) reducing to purple water-soluble formazans as cell-viability indicators. Bioorganic\&Medicinal Chemistry Letters, $1,11,611-614$.
Borenfreund E, Puerner JA, 1985: Toxicity determined in vitro by morphological alterations and neutral red absorption. Toxicol Lett, 24(2-3), 119-124.

Connolly DT, Knight MB, Harakas NK, Wittwer AJ, Feder J, 1986: Determination of the number of endothelial cells in culture using an acid phosphatase assay. Anal Biochem, 152, 136-140.

Crouch SPM, Kozlowski R, Slater KJ, Fletcher J, 1993: The use of ATP bioluminescence as a measure cell proliferation and cytotoxicity. J Immunol Methods, 160, 81-88.

Decker T, Lohmann-Matthes ML, 1988: A quick and simple method for the quantitation of lactate dehydrogenase release in measurements of cellular cytotoxicity and tumor necrosis factor (TNF) activity. $J$ Immunol Methods, 15, 61-69.

Denizot F, Lang R, 1986: Rapid colorimetric assay for cell growth and survival: Modifications to the tetrazolium dye procedure giving improved sensitivity and reliability. J Immunol Methods, 89, 271-277.

Duellman SJ, Zhou W, Meisenheimer P, Vidugiris G, Cali JJ, Gautam P, Wennerberg K, Vidugiriene J, 2015: Bioluminescent, nonlytic, real-time cell viability assay and use in inhibitor screening. Assay Drug Dev Techn,13(8), 456-465.

Erb RE, Ehlers MH, 1950: Resazurin reducing time as an indicator of bovine semen fertilizing capacity. J Dairy Sci, 33(12), 853-864.

Fan F, Wood KV, 2007: Bioluminescent assays for highthroughput screening.Assay Drug Dev Techn, 5, 1, 127-136.

Feoktistova M, Geserick P, Leverkus M, 2016: Crystal violet assay for determining viability of cultured cells. Cold Spring Harbor Protocol, DOI:10.1101/pdb.prot087379.

Galluzzi L et al, 2009: Guidelines for the use and interpretation of assays for monitoring cell death in higher eukaryotes. Cell Death Differ, 16, 1093-1107

Gilbert DF, Boutros M, 2016: A protocol for a highthroughput multiplex cell viability assay. Methods Mol Biol, 1470, 75-84

Held P, 2004: Luciferase Measurements Using the Clarity $^{\mathrm{TM}}$ Luminescence Microplate Reader. http://www.biotek.com/resources/articles/luciferas e-measurements-plate-reader.html, Erişim tarihi; 29.12.2016.

Ishiyama M, Tominaga H, Shiga M, Sasamoto K, Ohkura Y, Ueno K, Watanabe M, 1995: Novel cell proliferation and cytotoxicity assays using a tetrazolium salt that produce formazan dye. In Vitro Toxicology, 8, 187190.

Korzeniewski C, Callewaert DM, 1983: An enzyme-release assay for natural cyotoxicity. J Immunol Methods, 64, 313-320.

Lappalainen K, Jääskeläinen I, Syrjänen K, Urtti A, Syrjänen S, 1994: Comparison of cell proliferation and toxicity assays using two cationic liposomes. Pharm Res, 11(8), 1127-1131. 
Lomakina GY, Modestoca YA, Ugarova NN, 2015: Bioluminescence assay for cell viability. Biochemistry (Mosc), 80(6), 701-713.

Longo-Sorbello GSA, Saydam G, Banerjee D, Bertino JR, 2006: Cytotoxicity and cell growth assays. In "Cell biology: a laboratory handbook", Ed; Celis JE, Elseiver Academic Press, Burlington.

Martin A, Clynes M, 1993: Comparison of 5 microplate colorimetric assays for in vitro cytotoxicity testing and cell proliferation assays. Cytotechnology, 11, 4958.

Mossman T, 1983: Rapid colorimetric assay for cellular growth and survival: Application to proliferation and cytotoxicity assays. J Immunol Methods, 65, 55-63.

Niles AL, Moravec RA, Hesselberth PE, Scurria MA, Daily WJ, Riss TL, 2007: A homogeneous assay to measure live and dead cells in the same sample by detecting different protease markers. Anal Biochem, 336, 2, 197-206.

O'Brien J, Wilson I, Orton T, Pognan F, 2000: Investigation of the alamar blue (resazurin) fluorescent dye for the assessment of mammalian cell cytotoxicity. Federation Of European Biochemical Societies, 267, 17, 5421-5426.

O'Connor R, Heenan M, Duffy C, Clynes M, 1998: Miniaturized in vitro methods in toxicity testing. In "Animal Cell Culture Techniques", Ed; Clynes M, Springer Verlag, Germany.

Paull KD, Shoemaker RH, Boyd MR, Parsons JL, Risbood PA, Barbera WA, Sharma MN, Baker DC, Hand E, Scudiero DA, Monks A, Alley MC, Grote M, 1988: The synthesis of XTT: A new tetrazolium reagent that is bioreducible to a water-soluble formazan. $J$ Heterocyclic Chem, 25, 911-914.

Petty RD, Sutherland LA, Hunter EM, 1995: Comparison of MTT and ATP-based assays for the measurement of viable cell number. Luminescence, 10, 1, 29-34.

Riss T, Moravec R, 2002: Introducing the CytoTox-ONE ${ }^{\mathrm{TM}}$ homogeneous membrane integrity assay. Promega Notes, 82, 15-18.

Riss TL, Moravec RA, Niles AL, Duellmann S, Benink HA, Worzella TJ, Minor L, 2016: Assay guidance manual: cell viability assays. https://www.ncbi.nlm.nih.gov /books/NBK144065/?report=reader\#!po=1.16279, Erişim tarihi; 21.12.2016.

Riss TL, Moravec RA, O'brien MA, Hawkins EM, Niles A, 2006: Homogeneous multiwell assays for measuring cell viability, cytotoxicity, and apoptosis. In "Handbook Of Assay Development In Drug Discovery", Ed; Minor LK, CRC Press, Florida, USA.
Riss TL, Moravec RA, 2006: Cell proliferation assays: improved homogeneous methods used to measure the number of cells in culture. In "Cell Biology", Ed; Celis JE, Elseiver Academic Press, Burlington.

Riss TL, Moravec RA, 2004: Use of multiple assay endpoints to investigate the effects of incubation time, dose of toxin, and plating density in cell-based cytotoxicity assays. Assay Drug Dev Techn, 2, 1, 5162.

Sali N, Nagy S, Poór M, Köszegi T, 2016: Multiparametric luminescent cell viability assay in toxicology models: A critical evaluation. J Pharmacol Toxicol Methods, 79, 45-54.

Scudiero DA, Shoemaker RH, Kenneth DP, Monks A, Tierney S, Nofziger TH, Currens MJ, Seniff D, Boyd MR, 1988: Evaluation of a soluble tetrazolium/formazan assay for cell growth and drug sensitivity in culture using human and other tumor cell lines. Cancer Res, 48, 4827-4833.

Silva FSG, Starostina IG, Ivanova VV, Rizvanoz AA, Oliveira PJ, Pereira SP, 2016: Determination of metabolic viability and cell mass using a tandem resazurin/sulforhodamine B assay. Curr Protoc Toxicol, 68, 2.24.1-2.24.15 DOI: 10.1002/cptx.1.

Squatrito RC, Connor JP, Buller RE, 1995: Comparison of a novel redox cell growth assay to the ATP bioluminescence assay. Gynecol Oncol, 58, 101-105.

Tominaga $H$, Ishiyama $M$, Ohseto $F$, Sasamoto K, Hamamoto T, Suzuki K, Watanabe M, 1999: A watersoluble tetrazolium salt useful for colorimetric cell viability assay. Analytical Communications, 36, 4750.

Verhaegen S, Coyle S, Connolly LM, O'loughlin, Clynes M, 1998: Cell cycle and cell death mechanism. In "Animal Cell Culture Techniques", Ed; Clynes M, Springer Verlag, Germany.

Weyermann J, Lochmann D, Zimmer A, 2005: A practical note on the use of cytotoxicity assays. Int J Pharm, 288, 369-376.

Zucco F, Angelis DI, Stammati A, 1998: Cellular Models for In Vitro Toxicity Testing. In "Animal Cell Culture Techniques", Ed; Clynes M, Springer Verlag, Germany.

*Yazışma Adresi: Orhan TOKUR

Ondokuz Mayıs Üniversitesi, Veteriner Fakültesi, Veteriner Farmakoloji ve Toksikolojisi Anabilim Dalı, Samsun, Türkiye.

e-mail: orhantokur@gmail.com 